\title{
Analisis Kesalahan Siswa Kelas XI SMA Pada Materi Matriks
}

\author{
Bella Putri Khairani ${ }^{1 *}$, Kartini² \\ 1*,2Program Studi Magister Pendidikan Matematika, Universitas Riau \\ Jalan Kampus Bina Widya KM 12.5, Pekanbaru, Riau, Indonesia \\ 1*bella.putri2030@grad.unri.ac.id; ${ }^{2}$ kartini@lecturer.unri.ac.id
}

Artikel diterima: 26-01-2021, direvisi: 29-09-2021, diterbitkan: 30-09-2021

\begin{abstract}
Abstrak
Kebanyakan siswa SMA mengalami kesulitan dalam menyelesaikan soal matematika sehingga menyebabkan siswa melakukan kesalahan-kesalahan dalam penyelesaian soal. Tujuan penelitian ini untuk menganalisis kesalahan-kesalahan yang dilakukan siswa dalam mengerjakan soal pada materi matriks. Jenis penelitian ini adalah penelitian deskriptif kualitatif. Instrumen pada penelitian ini adalah instrumen tes. Subjek penelitian yaitu 30 siswa XI MIA 1 SMAN 15 Pekanbaru. Hasil analisis kesalahan dalam penelitian ini menunjukkan bahwa siswa melakukan kesalahan dalam menyelesaikan soal matematika berupa kesalahan fakta, kesalahan konsep, kesalahan prinsip dan kesalahan operasi. Persentase kesalahan yang dilakukan siswa pada kesalahan fakta sebesar $18,3 \%$, persentase pada kesalahan konsep sebesar $26,1 \%$, persentasi pada kesalahan prinsip sebesar $25,6 \%$, dan persentase pada kesalahan operasi sebesar $25 \%$. Jenis kesalahan yang paling banyak dilakukan oleh siswa adalah kesalahan konsep. Kesalahan konsep terjadi disebabkan siswa belum memahami konsep materi sehingga menyebabkan siswa kesulitan dalam menyelesaikan soal matematika.

Kata Kunci: Analisis, Kesalahan Siswa, Matriks.
\end{abstract}

\section{The Analysis of Student Errors of Class XI Senior High School Students on Matrix Material}

\begin{abstract}
Most high school students have difficulty in solving math problems, causing students to make mistakes in solving problems. This study aimed to analyze students' mistakes in working on the problem in the matrix material. This type of research is descriptive qualitative research. The instruments in this study are test instruments. The research subjects were 30 students of XI MIA 1 SMAN 15 Pekanbaru. The error analysis results showed that students made mistakes in solving math problems in factual errors, concept errors, principle errors, and operating errors. Students' percentage of errors on factual errors was $18.3 \%$, the percentage on conceptual error was $26.1 \%$, the percentage on principle error was $25.6 \%$, and the percentage on operating errors was $25 \%$. The most common type of mistake made by students is a conceptual error. The concept error occurs because the student does not understand the material's concept, causing students difficulty in solving math problems.

Keywords: Analysis, Student Error, Matrix.
\end{abstract}




\section{Pendahuluan}

Pendidikan adalah usaha sadar dan terencana untuk menciptakan suasana dalam proses pembelajaran, agar peserta didik dapat secara aktif mengembangkan potensi dirinya, sehingga memiliki kekuatan spiritual keagamaan, pengendalian diri, kepribadian, akhlak mulia, serta keterampilan yang diperlukan dirinya, masyarakat, bangsa dan negara (Raharjo, 2010; Rizky \& Sritresna, 2021; Astriandini \& Kristanto, 2021). Untuk meningkatkan mutu pendidikan, sekolah dituntut untuk bisa mempersiapkan diri siswa agar memiliki berbagai kemampuan yang bisa digunakan dalam berbagai hal yang diperlukan oleh siswa, sehingga siswa mempunyai kualitas dan meningkatkan prestasi siswa. IImu matematika merupakan bagian dalam bidang ilmu pendidikan (Nofyanti Dewi, 2020; Purnamasari \& Afriansyah, 2021).

Matematika sebagai suatu disiplin ilmu (Yunita, Juwita, \& Kartika, 2021; Asdar, Arwadi, \& Rismayanti, 2021) memiliki tujuan pembelajaran yang tercantum dalam Permendikbud No. 59 Tahun 2014 tentang Kurikulum 2013 SMA/MA adalah adalah: (1) Memahami konsep matematika, yaitu menjelaskan hubungan antar konsep, serta menerapkan konsep dan algoritma untuk menyelesaikan masalah secara fleksibel, akurat, efisien, dan akurat; (2) Menggunakan pola sebagai dugaan untuk menyelesaikan masalah dan mampu mendasarkan pada fenomena atau data yang ada untuk digeneralisasi; Menggunakan penalaran kualitatif untuk melakukan operasi matematika, termasuk memahami masalah, menetapkan model matematika, menyempurnakan model, dan menjelaskan solusi yang diperoleh, serta kemampuan memecahkan masalah dalam kehidupan sehari-hari; (4) Saling bertukar pikiran dan menalar, serta mampu menyusun bukti-bukti matematika; (5) Memiliki sikap menghargai kegunaan matematika dalam kehidupan; (6) Memiliki sikap dan perilaku yang sesuai dengan nilai matematika dan pembelajaran; Menggunakan pengetahuan matematika untuk kegiatan motorik; dan (8) menggunakan alat peraga sederhana maupun hasil teknologi untuk melakukan kegiatan matematik.

Jika proses pembelajaran masih didominasi oleh guru dan tidak berpusat pada siswa, maka tujuan pembelajaran matematika tidak akan tercapai (Silviani \& Mardiani, 2021). Guru hanya menjelaskan materi pelajaran dengan memberikan contoh soal dan latihan soal secara rutin, karena itu jika siswa diberikan soal tidak rutin maka siswa akan mengalami kebingungan dan kesulitan dalam menyelesaikan soal (Fuadi, Johar, \& Munzir, 2016; Rahmayanti \& Maryati, 2021). Dikarenakan banyaknya kesulitan yang dihadapi siswa dalam menyelesaikan soal matematika membuat siswa melakukan kesalahan-kesalahan dalam pengerjaannya (Latifah \& Afriansyah, 2021). Kesulitan-kesulitan yang dihadapi siswa dalam proses pembelajaran matematika menyebabkan kurangnya minat siswa dalam mempelajari matematika terutama pada materi matriks (Ramziah, 2016). Matriks merupakan salah satu materi yang diajarkan ditingkat sekolah menengah atas (SMA) yang dianggap tidak mudah bagi siswa. 
Salah satu kesalahan yang sering di lakukan siswa adalah masih sulit memahami maksud dari perintah soal, siswa hanya terbiasa memahami soal-soal yang masih terbilang sederhana (Nurkamilah \& Afriansyah, 2021). Saat diberikan soal-soal yang sudah bervariasi, siswa mengalami kekeliruan dalam menyelesaikan soal tersebut. Selain itu, kebanyakan siswa mengalami kesalahan pada operasi perkalian antara dua matriks dikarenakan siswa masih sulit untuk memahami konsep, dan siswa juga sering salah dalam melakukan perhitungan akibat kurang teliti dan ceroboh (Wahyuni Koem, 2014). Hal itu juga didukung oleh penelitian Yulianingsih \& Dwinata (2018) yang juga menyebutkan kesalahan yang terus menerus terjadi didukung oleh kemampuan penguasaan materi pada siswa yang kurang.

Kesalahan menurut Wijaya (dalam Rahmania, 2016) adalah bentuk penyimpangan pada sesuatu hal yang telah dianggap benar atau bentuk penyimpangan terhadap sesuatu yang telah disepakati atau ditetapkan sebelumnya. Lipianto (2013) menyebutkan kesalahan juga terjadi akibat dari rendahnya tingkat kemampuan pelajaran melainkan disebabkan karena tingkat pemahaman siswa yang kurang mendalam.

Abd. Rahman Habie (2015) dalam hasil penelitiannya menyebutkan bahwa kesalahan siswa kelas XI dalam belajar matematika pada materi matriks terjadi pada 4 jenis kesalahan yaitu kesalahan konsep, kesalahan operasi, kesalahan fakta dan kesalahan prinsip. Berdasarkan hasil penelitian Cici Rezki (2015) dapat disimpulkan bahwa kesalahan yang paling banyak dilakukan oleh siswa dalam menyelesaikan soal matematika materi matriks adalah kesalahan konsep dengan persentase kesalahannya sebesar 57,24\%.

Siswa kelas XI MIA 1 SMAN 15 Pekanbaru yang berjumlah 30 orang merupakan para siswa yang berada pada kelas unggulan. Berdasarkan data hasil ulangan harian pada materi sebelumnya diperoleh informasi bahwa nilai siswa mengalami penurunan. Peneliti melakukan wawancara dengan beberapa siswa dan diperoleh penyebab menurunnya kemampuan siswa dikarenakan siswa kurang paham materi yang dipelajari, siswa kebanyakan hanya menghafal langkahlangkah yang disajikan oleh guru tanpa memahami konsepnya.

Berdasarkan fakta di atas, peneliti berupaya untuk mengatasi permasalahan pada siswa dengan mendeskripsikan kesalahan-kesalahan siswa dalam menyelesaikan masalah matematika. Analisis terhadap kesalahan-kesalahan siswa perlu dilakukan, melalui analisis ini akan diketahui jejak, jenis dan penyebab kesalahan, sehingga guru dapat memberikan jenis bantuan kepada siswa yang relevan berdasarkan hasil analisis yang ditemukan (Sunyono, dkk., 2015).

Kesalahan matematika dalam penelitian ini ditinjau dari objek matematika yang terdiri dari: (1) kesalahan fakta; (2) kesalahan konsep; (3) kesalahan prinsip; dan (4) kesalahan operasi (Soedjadi, 2000). Upaya yang dilaksanakan dalam penelitian ini adalah menganalisis kesalahan siswa dalam menyelesaikan soal matriks yaitu: (1) konsep kesamaan dua matriks; 
penjumlahan, pengurangan, perkalian skalar pada matriks; (3) perkalian dua matriks; dan (4) transpose matriks.

Diharapkan hasil dari penelitian ini dapat meningkatkan kemampuan para siswa khususnya dalam bidang matematika serta bisa berguna untuk siapapun yang membaca agar bisa mengetahui kesalahan yang dilakukan siswa dalam mengerjakan soal matematika pada materi matriks.

\section{Metode}

Jenis penelitian ini merupakan penelitian deskriptif kualitatif. Menurut Umar Sidiq (2019) penelitian kualitatif adalah penelitian yang bertujuan memahami fenomena yang dirasakan oleh subyek penelitian misalnya sikap, anggapan, motivasi, tindakan, dan sebagainya. Pendekatan kualitatif digunakan untuk mengetahui letak kesalahan yang dilakukan siswa.

Instrumen yang digunakan dalam penelitian ini adalah instrumen tes yang terdiri dari 6 soal uraian yang berkaitan dengan materi matriks. Soal tes diuji untuk mengetahui validitas, reliabilitas, daya pembeda dan tingkat kesukarannya. Berdasarkankan hasil uji coba instrument tes, indeks korelasi sebesar 0,84. Ini menunjukkan bawa soal tes yang dibuat memiliki validitas sangat tinggi, begitu pula dengan reliabilitasnya yang bernilai 0,91.

Data hasil tes diolah dan dianalisis dengan mengacu pada pedoman penskoran. Data dideskripsikan secara kuantitatif dalam bentuk persentase kesalahan peserta didik berdasarkan tingkat kemampuan matematika siswa pada materi dengan rumus:

$$
\begin{aligned}
& P=100 \%-\left(\frac{\text { skor yang diperoleh siswa }}{\text { skor total }} \times 100 \%\right) \\
& \text { Adapun soal tes beserta indikator } \\
& \text { pencapaian kompetensi yang digunakan } \\
& \text { sebagai berikut: }
\end{aligned}
$$

Soal nomor 1 mengenai konsep matriks, ordo matriks, jenis matriks, dan kesamaan dua matriks dengan indikator soal yaitu diberikan dua matriks yang sama, peserta didik dapat menentukan unsur-unsur matriks yang belum diketahui (dapat dilihat pada Gambar 1).

Diketahui matriks $\mathrm{A}=\left[\begin{array}{cc}9 & 2 x \\ y & 10\end{array}\right], \mathrm{B}=\left[\begin{array}{cc}3 a & 12 \\ 5 & 2 b\end{array}\right]$.
Jika $\mathrm{A}=\mathrm{B}$, maka tentukanlah nilai $\mathrm{a}, \mathrm{b}, \mathrm{x}$ dan $\mathrm{y}$.

Gambar 1. Soal Nomor 1.

Soal nomor 2 mengenai penjumlahan, pengurangan, perkalian skalar pada matriks dengan indikator soal yaitu diberikan dua matriks yang berordo sama, peserta didik dapat menentukan penjumlahan dari hasil perkalian skalar dengan setiap matriks (dapat dilihat pada Gambar 2).

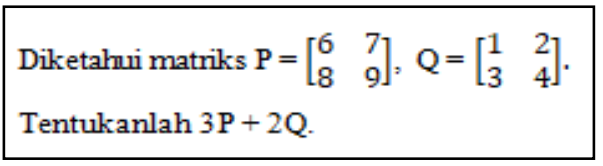

Gambar 2. Soal Nomor 2.

Soal nomor 3 mengenai perkalian dua matriks dengan indikator soal yaitu diberikan dua matriks yang berordo berbeda dan memenuhi syarat perkalian dua matriks, peserta didik dapat menentukan hasil perkalian dua matriks tersebut (dapat dilihat pada Gambar 3).

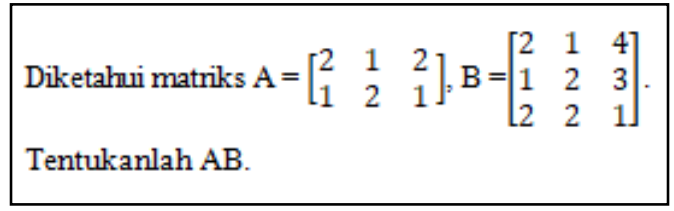

Gambar 3. Soal Nomor 3 
Soal nomor 4 mengenai transpose matriks dengan indikator soal yaitu diberikan tiga matriks berordo sama, peserta didik dapat menentukan transpose dari tiga matriks tersebut. (dapat dilihat pada Gambar 4).

Diketahui matriks $X=\left[\begin{array}{cc}2 & -1 \\ 1 & 4\end{array}\right], Y=\left[\begin{array}{ll}5 & 2 \\ 3 & 4\end{array}\right], Z=\left[\begin{array}{ll}7 & 2 \\ 3 & 1\end{array}\right]$.

Tentukantranspose darimatriks X, Y dan Z.

Gambar 4. Soal Nomor 4.

Soal nomor 5 mengenai permasalahan kontekstual dengan menggunakan konsep operasi penjumlahan matriks, pengurangan matriks, dan perkalian skalar dengan matriks dengan indikator soal yaitu diberikan sebuah permasalahan mengenai lima matriks yang berordo sama dengan tiga kategori berbeda, peserta didik dapat menentukan hasil dari penjumlahan pada matriks yang berkategori sama pertama, pengurangan pada matriks berkategori kedua dan menentukan hasil perkalian skalar dengan matriks berkategori ketiga (dapat dilihat pada Gambar 5).

\begin{tabular}{|l|}
\hline Di suatupasarterdapat tiga orangpedagangjeruk dansalak. Buah \\
yang dijual berkualitas tinggi dan sedang. Pada hari pertama \\
berjualan, ketiga pedagang membeli jeruk dan salak dengan \\
jumlah yang sama pada seorang agen buah, yaitu $11 \mathrm{~kg}$ jeruk \\
kualitas sedang, $15 \mathrm{~kg}$ jeruk kualitas tinggi, $13 \mathrm{~kg}$ salak kualitas \\
sedang, dan $12 \mathrm{~kg}$ salak dengan kualitas tinggi. Di hari kedua, \\
pedagang pertama menambah pembelian buah sebanyak $9 \mathrm{~kg}$ \\
jeruk kualitas sedang, $7 \mathrm{~kg}$ jeruk kualitas tinggi, $6 \mathrm{~kg}$ salak \\
kualitas sedang, dan $8 \mathrm{~kg}$ salak dengan kualitas tinggi. Pedagang \\
keduamengurangipembelianbuah yang akan dijual sebanyak 3 \\
kg jeruk kualitas sedang, $5 \mathrm{~kg}$ jeruk kualitas tinggi, $2 \mathrm{~kg}$ salak \\
kualitas sedang, dan $4 \mathrm{~kg}$ salak dengan kualitas tinggi. Pedagang \\
ketiga menanbah pembelian buah yang akan dijual sebanyak 3 \\
kali. \\
a. Sajikan masalah diatas ke dalam bentuk matriks. \\
b. Berapakgjumlahbuahyang dibeli masing-masingpedagang \\
di hari kedua?
\end{tabular}

Gambar 5. Soal Nomor 5.

Soal nomor 6 mengenai permasalahan kontekstual dengan menggunakan konsep transpose matriks dengan indikator soal yaitu diberikan sebuah permasalahan mengenai dua matriks yang berordo berbeda, peserta didik dapat mentransposekan salah satu matriks agar memenuhi syarat perkalian dua matriks dan menentukan penjumlahan dari hasil perkalian tersebut (dapat dilihat pada Gambar 6).

\begin{tabular}{|c|c|c|c|c|c|}
\hline \multicolumn{6}{|c|}{$\begin{array}{l}\text { Berat badan Efri a dalah } S 0 \mathrm{~kg} \text {. I a ingin mengurangi berat badanny a melalu } \\
\text { satu rencana diet danlatihan fisik. Sesudahmentuat tabel rencana aktivitas } \\
\text { harian Tabel } 1 \text {, ia mencari tahu rangkaian aktivitas fisik: untuk dapat } \\
\text { membantunya menurunkan berat badan serta jumlah kalori yang dapat } \\
\text { terbakar seperti pada Tabel : } \\
\text { Tabel } 1 \text { Aktivitas harian }\end{array}$} \\
\hline \multirow{2}{*}{$\begin{array}{l}\text { Jadwa! } \\
\text { lathan }\end{array}$} & Senin & Selasa & Kabu & Kamis & Jumat \\
\hline & \multicolumn{5}{|c|}{ (dalamjam) } \\
\hline falan & 1 & 0 & 1 & 0 & 1 \\
\hline $\operatorname{lan}$ & 0 & 0.5 & 0 & 0.5 & 0 \\
\hline Bersepeda & 1 & 0.5 & 1 & 0.5 & 1 \\
\hline Berenang & 0.5 & 0.5 & 0,5 & 0,5 & 0,5 \\
\hline \multicolumn{6}{|c|}{ Tabel: Jundahkalori yarg dapat terbakax } \\
\hline \multicolumn{2}{|c|}{ Aktiñtas latưhan f̂̉ik } & \multicolumn{2}{|c|}{ Berat (SO kg) } & & \\
\hline \multicolumn{2}{|c|}{ Jalankaki jam } & \multicolumn{2}{|c|}{255 kalori } & & \\
\hline \multicolumn{2}{|c|}{ Lari jam } & \multicolumn{2}{|c|}{ 7S kalori } & & \\
\hline \multicolumn{2}{|c|}{ Bersepeda jam } & \multicolumn{2}{|c|}{950 kalori } & & \\
\hline \multicolumn{2}{|c|}{ Berenang jam } & \multicolumn{2}{|c|}{ S40 kalori } & & \\
\hline \multicolumn{6}{|c|}{$\begin{array}{l}\text { Kka Efin mengikuti rencana ini berapa kalori y'ang ak an terbakar dengan } \\
\text { melakukan latihan selama lima hari? }\end{array}$} \\
\hline
\end{tabular}

Gambar 6. Soal Nomor 6 .

Penelitian dilakukan di SMAN 15 Pekanbaru. Penelitian dilakukan pada hari Rabu, 25 November 2020. Subjek dalam penelitian ini adalah siswa kelas XI MIA 1 SMAN 15 Pekanbaru semester ganjil yang berjumlah 30 siswa. Objek dalam penelitian ini adalah analisis kesalahan siswa dalam menyelesaikan soal uraian mata pelajaran matematika dalam pokok bahasan matriks.

\section{Hasil dan Pembahasan}

Hasil analisis pada tiap jenis kesalahan setelah 30 siswa mengerjakan soal sebanyak 6 butir dapat dilihat pada Tabel 1 . 
Tabel 1.

Persentase Kesalahan Siswa

\begin{tabular}{lccccccc|}
\hline \multirow{2}{*}{\begin{tabular}{c} 
Jenis \\
Kesalaha \\
\multicolumn{1}{c}{$n$}
\end{tabular}} & \multicolumn{6}{c}{$\begin{array}{c}\text { Persentase Kesalahan Siswa Pada Tiap } \\
\text { Nomor Soal (\%) }\end{array}$} & $\begin{array}{c}\text { Rata- } \\
\text { Rata }\end{array}$ \\
\cline { 2 - 8 } & 1 & 2 & 3 & 4 & 5 & 6 & \\
\hline Fakta & 10 & 0 & 13,3 & 0 & ${ }^{23,3}$ & 63,3 & $18,3 \%$ \\
\hline Konsep & 10 & 13,3 & ${ }^{33,3}$ & 16,7 & 33,3 & 80,3 & $26,1 \%$ \\
\hline Prinsip & 10 & 13,3 & 13,3 & 16,7 & 16,7 & 83,8 & $25,6 \%$ \\
\hline Operasi & 10 & 13,3 & 16,7 & 16,7 & 30 & 63,3 & $25 \%$ \\
\hline
\end{tabular}

Berdasarkan data persentase kesalahan siswa pada tabel 1, diperoleh hasil bahwa rata-rata persentase pada jenis kesalahan yang paling sedikit dilakukan siswa yaitu kesalahan fakta sebesar 18,3\%, kesalahan yang dilakukan siswa terkait lambanglambang atau simbol, huruf dan kata dalam menyelesaikan soal-soal matematika. Pada jenis kesalahan konsep, persentase kesalahan yang dilakukan siswa merupakan yang paling tinggi dari semua jenis kesalahan yaitu sebesar 26,1\%, kesalahan yang dilakukan siswa terkait bagaimana memahami atau menerapkan konsep dengan benar. Pada jenis kesalahan prinsip, persentase yang dilakukan siswa tidak sebesar sebelumnya yaitu 25,6\% kesalahan yang dilakukan siswa terkait dalam menyatakan berlakunya suatu hubungan antara beberapa konsep. Selanjutnya pada jenis kesalahan operasi, persentase kesalahan yang dilakukan siswa sebesar $25 \%$, kesalahan yang dilakukan siswa terkait dalam melakukan operasi perhitungan.

Analisis kesalahan siswa dalam menjawab soal berdasarkan objek matematika pada tiap butir soal dijelaskan sebagai berikut:

1) Soal Nomor 1

Soal nomor 1 adalah soal yang penyelesaiannya membutuhkan pemahaman tentang konsep kesamaan dua matriks. Siswa yang menjawab soal nomor
1 sebanyak 30 orang dan sebanyak 3 orang melakukan kesalahan dalam penyelesaian soal tersebut. Siswa salah dalam menentukan salah satu nilai unsur matriks yaitu y. Seharusnya nilai unsur y adalah 5 .

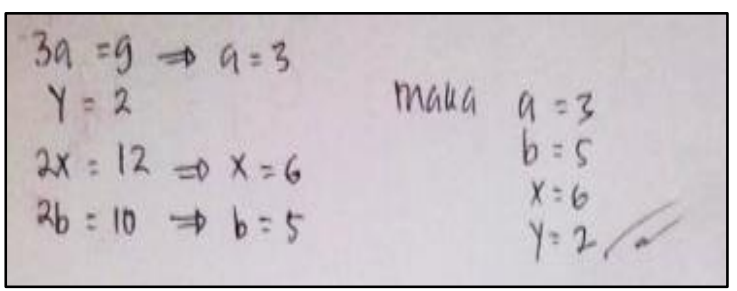

Gambar 7. Respon Siswa terhadap Soal Nomor 1.

\section{2) Soal Nomor 2}

Soal nomor 2 adalah soal yang penyelesaiannya membutuhkan pemahaman tentang penjumlahan matriks dan perkalian skalar dengan matriks. Siswa yang menjawab soal nomor 2 sebanyak 30 orang dan tidak terdapat siswa yang melakukan kesalahan dalam penyelesaian soal tersebut. Dimana siswa menjawab dengan benar dan sesuai dengan langkahlangkah pengerjaannya.

3) Soal Nomor 3

Soal nomor 3 adalah soal yang penyelesaiannya membutuhkan pemahaman tentang konsep perkalian dua matriks. Siswa yang menjawab soal nomor 3 sebanyak 30 orang dan sebanyak 10 orang melakukan kesalahan dalam menyelesakan soal. Kesalahan yang dilakukan siswa adalah menuliskan simbol "+" pada operasi perkalian dua matriks, seharusnya siswa menuliskan simbol perkalian (dapat dilihat pada Gambar 8). Kesalahan yang dilakukan siswa lainnya adalah kesalahan pada konsep perkalian dua matriks, siswa salah dalam mengalikan baris pertama dengan kolom kedua pada matriks (dapat dilihat pada Gambar 9). 
Berdasarkan penelitian Sugita (2019) yang menyatakan kesalahan konsep perkalian matriks disebabkan kekeliruan yang dilakukan siswa, rata-rata siswa berfikir bahwa suatu matriks dapat dikalikan hanya jika ordo dari matriks yang akan dikalikan itu sama, sehingga ketika menemukan matriks yang memiliki ordo yang berbeda siswa langsung salah ketika mengalikan anggota matriks tersebut.

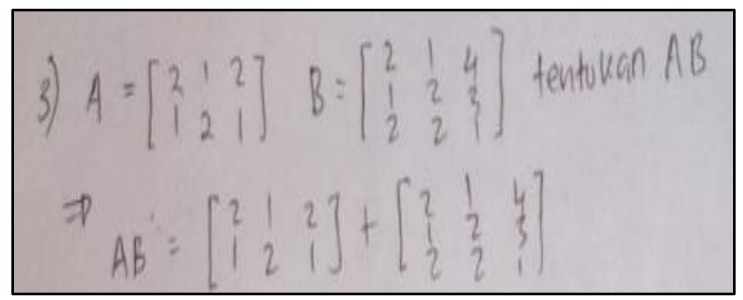

Gambar 8. Respon Siswa terhadap Soal Nomor 3.

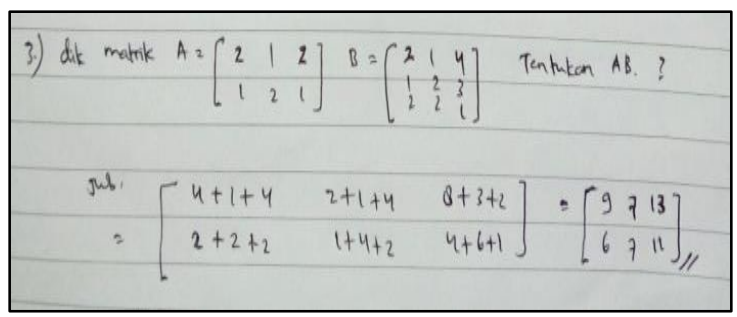

Gambar 9. Respon Siswa Lainnya terhadap Soal Nomor 3.

4) Soal Nomor 4

Soal nomor 4 adalah soal yang penyelesaiannya membutuhkan pemahaman tentang transpose matriks. Siswa yang menjawab soal nomor 4 sebanyak 30 orang dan tidak terdapat siswa yang melakukan kesalahan dalam penyelesaian soal tersebut. Dimana siswa menjawab dengan benar dan sesuai dengan langkah-langkah pengerjaannya.

5) Soal Nomor 5

Soal nomor 5 adalah soal yang penyelesaiannya membutuhkan pemahaman tentang penjumlahan, pengurangan dan perkalian skalar dengan matriks. Siswa yang menjawab soal nomor 5 sebanyak 30 orang dan sebanyak 10 orang melakukan kesalahan dalam menyelesaikan soal. Kesalahan yang dilakukan siswa adalah kesalahan konsep penjumlahan, pengurangan dan perkalian skalar pada matriks. Siswa salah dalam memahami konsep soal cerita dan pertanyaan. Seharusnya siswa menjumlahkan, mengurangkan dan mengalikan buah ketiga pedagang pada hari kedua akan tetapi peserta didik mengurangkan buah pedagang kedua dengan buah pedagang ketiga (dapat dilihat pada Gambar 10). Kesalahan yang dilakukan siswa lainnya adalah kesalahan dalam operasi pengurangan. Siswa salah menuliskan angka 11 dengan angka 12, sehingga hasil akhir pengurangannya salah. Seharusnya peserta didik menuliskan 11 - 3 $=8$ (dapat dilihat pada Gambar 11).

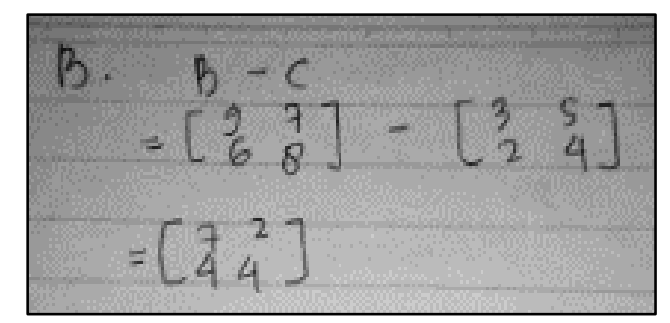

Gambar 10. Respon Siswa terhadap Soal Nomor 5.

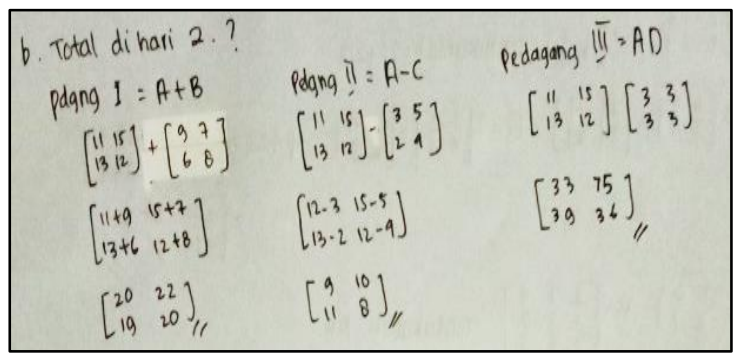

Gambar 10. Respon Siswa Lainnya terhadap Soal Nomor 5. 
6) Soal Nomor 6

Soal nomor 6 adalah soal yang penyelesaiannya membutuhkan pemahaman tentang penjumlahan, pengurangan dan perkalian skalar dengan matriks. Siswa yang menjawab soal nomor 6 sebanyak 30 orang dan sebanyak 25 orang melakukan kesalahan dalam menyelesaikan soal tersebut. Kesalahan yang dilakukan siswa adalah kesalahan konsep perkalian dua matriks. Siswa langsung mengalikan kedua matriks tanpa memperhatikan syarat perkalian dua matriks terlebih dahulu. Seharusnya siswa mentransposekan salah satu matriks agar syarat perkalian dua matriks terpenuhi, setelah itu dilanjutkan dengan melakukan perkalian dua matriks.

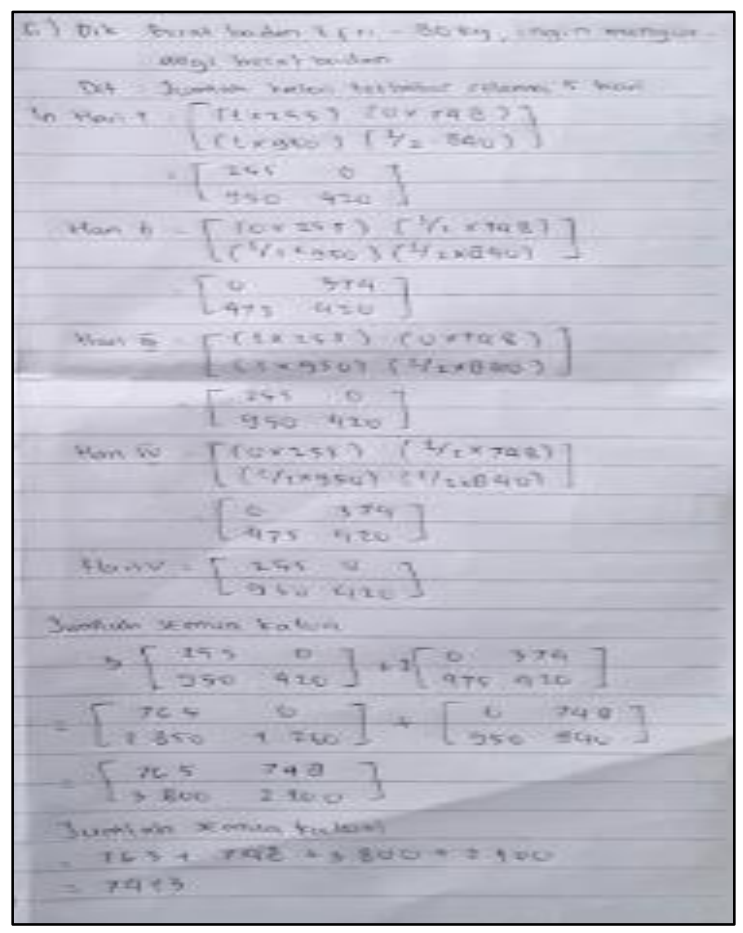

Gambar 11. Respon Siswa terhadap Soal Nomor 6.

\section{Penutup}

Berdasarkan hasil pembahasan dalam mengerjakan soal matriks, dapat disimpulkan bahwa jenis kesalahan yang dilakukan siswa adalah kesalahan fakta, konsep, prinsip dan operasi. Jenis kesalahan yang paling banyak yang dilakukan oleh siswa dalam menyelesaikan soal matematika pada materi matriks adalah kesalahan konsep, dengan persentase kesalahannya sebesar 26,1\%. Kesalahan konsep terjadi disebabkan karena siswa belum memahami konsep materi yang menyebabkan siswa kesulitan dalam menyelesaikan soal, sejalan dengan pendapat Utami (2012), Mardiani (2017), Sari \& Afriansyah (2020), dan Gustianingrum \& Kartini (2021) bahwa kesalahan konsep yang dilakukan siswa disebabkan ketidaktahuan dan ketidakpahaman siswa akan konsep, sehingga banyak konsep yang dipahami siswa secara keliru.

Diharapkan pada proses pembelajaran harus lebih mengutamakan siswa sebagai pusat pembelajaran agar siswa memahami konsep, sehingga siswa tidak hanya terjebak dalam proses menghafal rumus serta prosedur saja.

\section{Daftar PUStaka}

Asdar, A., Arwadi, F., \& Rismayanti, R. (2021). Pendekatan Pendidikan Matematika Realistik terhadap Hasil Belajar Matematika dan Self Confidence Siswa SMP.Plusminus: Jurnal Pendidikan Matematika, 1(1), 116.

Astriandini, M. G., \& Kristanto, Y. D. (2021). Kajian Etnomatematika Pola Batik Keraton Surakarta Melalui Analisis Simetri. Mosharafa: Jurnal Pendidikan Matematika, 10(1), 13-24.

Depdikbud. (2014). Permendikbud No. 59 Tahun 2014 tentang Kurikulum 2013 
Sekolah Menengah Atas/MA. Jakarta: Kemendikbud.

Dewi, N., \& Zanthy, L. S. (2020). Analisis Kesalahan Pada Siswa Kelas XI Dalam Mengerjakan Soal Materi Matriks. Histogram: Jurnal Pendidikan Matematika, 4(1).

Fuadi, R., Johar, R., \& Munzir, S. (2016). Peningkatkan kemampuan pemahaman dan penalaran matematis melalui pendekatan kontekstual. Jurnal Didaktik Matematika, 3(1), 47-54.

Gustianingum, R. A., \& Kartini, K. (2021). Analisis Kesalahan Siswa Berdasarkan Objek Matematika Menurut Soedjadi pada Materi Determinan dan Invers Matriks. Mosharafa: Jurnal Pendidikan Matematika, 10(2), 235-244.

Habie, A. R. (2016). Analisis Kesulitan Siswa Kelas XI IPA Dalam Belajar Matematika Pada Materi Matriks (Studi Penelitian di Kelas XI IPA SMA Negeri 1 Anggrek Kab. Gorontalo Utara). Skripsi, 1(411410028).

Koem, S. W. (2014). Analisis Kesalahan Siswa Dalam Menyelesaikan Soal-Soal Matriks Pada Siswa Kelas XII SMA (Suatu Penelitian di SMA Negeri 1 Sumalata Kelas XII IPA). Skripsi, 1(411409095).

Lipianto, D., Budiarto, M. T., Matematika, J., Surabaya, U. N., Matematika, J., \& Surabaya, U. N. (2013). Analisis kesalahan siswa dalam menyelesakan soal yang berhubungan dengan persegi dan persegipanjang berdasarkan taksonomi solo plus pada kelas vii. MATHEdunesa Jurnal IImiah Pendidikan Matematika, 2(1).
Latifah, T., \& Afriansyah, E. A. (2021). Kesulitan dalam Kemampuan Pemecahan Masalah Matematis Siswa pada Materi Statistika. Journal of Authentic Research on Mathematics Education (JARME), 3(2), 134-150.

Mardiani, D. (2017). Eksploitasi Kesalahan Konsep Teori Graf dalam Perkuliahan Matematika Diskrit Menggunakan Metode Game" Tantangan Berhadiah Point". Mosharafa: Jurnal Pendidikan Matematika, 6(3), 365-372.

Nurkamilah, P., \& Afriansyah, E. A. (2021). Analisis Miskonsepsi Siswa pada Bilangan Berpangkat. Mosharafa: Jurnal Pendidikan Matematika, 10(1), 49-60.

Purnamasari, A., \& Afriansyah, E. A. (2021). Kemampuan Komunikasi Matematis Siswa SMP pada Topik Penyajian Data di Pondok Pesantren. Plusminus: Jurnal Pendidikan Matematika, 1(2), 207-222.

Raharjo, S. B. (2010). Pendidikan karakter sebagai upaya menciptakan akhlak mulia.Jurnal Pendidikan dan Kebudayaan, 16(3), 229-238.

Rahmania, L., \& Rahmawati, A. (2016). Analisis kesalahan siswa dalam menyelesaikan soal cerita persamaan linier satu variabel. JMPM: Jurnal Matematika Dan Pendidikan Matematika, 1(2), 165-174.

Rahmayanti, I., \& Maryati, I. (2021). Kesalahan Siswa SMP pada Soal Pemecahan Masalah Berdasarkan Tahapan Teori Newman. Plusminus: Jurnal Pendidikan Matematika, 1(1), 61-70.

Ramziah, S. (2016). Peningkatan Kemampuan Representasi Matematis 
Siswa Kelas X2 SMAN 1 Gedung

Meneng Menggunakan Bahan Ajar Matriks Berbasis Pendekatan

Saintifik. Mosharafa: Jurnal Pendidikan

Matematika, 5(2), 138-147.

Rezki, C. (2015). Analisis Kesalahan Siswa

Dalam Menyelesaikan Soal-Soal

Matriks di Kelas XII MAN Darussalam

Aceh Besar. ETD Unsyiah.

Rizky, E. N. F., \& Sritresna, T. (2021).

Peningkatan Kemampuan Berpikir

Kritis dan Disposisi Matematis Siswa

Antara Guided Inquiry dan Problem

Posing. Plusminus: Jurnal Pendidikan

Matematika, 1(1), 33-46.

Sari, H. M., \& Afriansyah, E. A. (2020).

Analisis Miskonsepsi Siswa SMP pada Materi Operasi Hitung Bentuk Aljabar. Mosharafa: Jurnal Pendidikan Matematika, 9(3), 439-450.

Sidiq, U., Choiri, M. M., \& Mujahidin, A. (2019). Metode Penelitian Kualitatif di Bidang Pendidikan. Ponorogo: Penerbit CV Nata Karya.

Silviana, D., \& Mardiani, D. (2021). Perbandingan Kemampuan

Pemahaman Matematis Siswa melalui Mood-Understand-Recall-Digest-

Expand-Review dan Discovery Learning. Plusminus: Jurnal Pendidikan Matematika, 1(2), 291-302.

Sugita, G. (2019). Profil Kesalahan Siswa

Dalam Menyelesaikan Soal Matriks Berdasarkan Jenis Kelamin Di Sma Negeri 7 Palu. Aksioma, 8(2), 110-124.

Sunyono, Y., L., \& Ibrahim, M. (2015). The Online Journal of New Horizons in Education. The Online Journal of New Horizons in Education, 5(2), 30-45.

Soedjadi, R. (2000). Kiat pendidikan matematika di Indonesia: konstatasi keadaan masa kini menuju harapan masa depan. Direktorat Jenderal Pendidikan Tinggi, Departemen Pendidikan Nasional.

Utami, W. T. (2012). Identifikasi Kesulitan dalam menyelesaikan Persoalan Matematika yang berkaitan dengan Pecahan di kelas VIII SMP N 3 Ngaglik Sleman tahun Ajaran 2011/2012. EJurnal Universitas Negeri Yogyakarta.

Yulianingsih, A., Febrian, F., \& Dwinata, A. (2018). Analisa Kesalahan Konsep Pecahan pada Siswa Kelas VII A SMP Negeri 13 Satu Atap Tanjungpinang. Mosharafa: Jurnal Pendidikan Matematika, 7(2), 199-206. Yunita, A., Juwita, R., \& Kartika, S. E. (2020). Pengaruh penerapan model pembelajaran kooperatif tipe teams games tournament terhadap hasil belajar matematika siswa. Mosharafa: Jurnal Pendidikan Matematika,9(1), 23-34.

\section{Riwayat Hidup PenUlis}

\section{Bella Putri Khairani, S.Pd.}

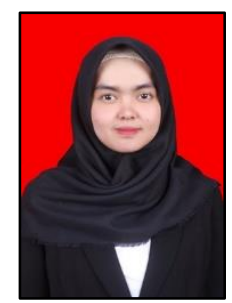

Lahir di Pekanbaru, 20 Maret 1997. Studi $S_{1}$ Pendidikan Matematika Universitas Riau, lulus tahun 2020; Mahasiswa $\mathrm{S}_{2}$ Pendidikan Matematika FKIP Universitas Riau, Pekanbaru.

\section{Dr. Kartini, M.Si.}

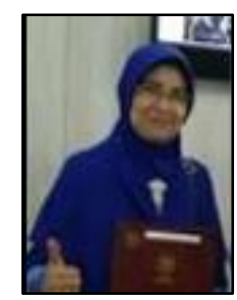

Lahir di Bagan Punak, 3 Juli 1972. Dosen Pascasarjana Pendidikan Matematika FKIP Universitas Riau. Studi $S_{1}$ Pendidikan Matematika Universitas Riau, lulus tahun 1997; S2 Matematika Institut Teknologi Bandung, lulus tahun 2001; $\mathrm{S}_{3}$ Pendidikan Matematika Universitas Pendidikan Indonesia, lulus tahun 2012. 